\title{
Working in the Air: Time Management and Work Intensification Challenges for Workers in Commercial Aviation
}

\author{
Anne Gillet ${ }^{1}$, Diane-Gabrielle Tremblay ${ }^{2 *}$ \\ ${ }^{1}$ Centre National des Arts et Métiers, Lise-CNRS, Paris, France \\ ${ }^{2}$ Université Téluq, University of Québec, Montréal, Canada \\ Email: anne.gillet@lecnam.net, *diane-gabrielle.tremblay@teluq.ca
}

How to cite this paper: Gillet, A., \& Tremblay, D.-G. (2021). Working in the Air: Time Management and Work Intensification Challenges for Workers in Commercial Aviation. Open Journal of Social Sciences, 9, 272290.

https://doi.org/10.4236/jss.2021.91020

Received: December 7, 2020

Accepted: January 22, 2021

Published: January 25, 2021

Copyright $\odot 2021$ by author(s) and Scientific Research Publishing Inc. This work is licensed under the Creative Commons Attribution International License (CC BY 4.0).

http://creativecommons.org/licenses/by/4.0/

(c) (i) Open Access

\begin{abstract}
In the air transport sector, the work of flight attendants is characterised by the diversity of their temporalities and working hours. The constraints of working time have impacts on the organization of other activities and social times of the staff. This text shows the diversity of working hours and the way they are articulated to other temporalities, in a working context where the cabin crew is constantly changing, working on different temporary teams. The paper analyses the regulations, the definition of working time and the specific method of calculating this chronological time dedicated to the work activity. It shows the intensification of work experienced by the flight attendants, the fragmentation and heterogeneity of working times. The constraints of atypical working hours are analysed through timetables and the tensions experienced between professional, family and personal times. Professional activities are characterised by a diversity of working and non-working times that are strongly interconnected. Some national particularities highlighted can offer interesting solutions to several difficulties experienced elsewhere and illustrate ways of adjusting or getting around the working time issues specific to the work of the flight attendants. This paper is based on theoretical and empirical research carried out with air hostesses, stewards and pursers employed in several regular, low-cost and charter airlines in Canada and in several European countries.
\end{abstract}

\section{Keywords}

Flight Attendants, Working Time, Work-Life Balance, Work Organisation, Women's Work

\section{Introduction}

While working hours are changing in many sectors of activity, the air transport 
sector is of great interest for research on working time, work schedules and more generally human resources and time management. Indeed, work schedules and HRM in aviation are very particular as they are submitted to working time regulations, as well as time constraints framing the professional activity of the cabin crew (cabin crew: hostesses, stewards and cabin directors). These time challenges have impacts on the organization of other activities and social times of the staff. However, if the air transport sector has a great diversity of working times and schedules, this is also observed in other service sectors (retail, hotels, and many others), hence the interest of this analysis of human resources and time management in the commercial aviation sector. We argue here that airline companies and managers should be attentive to working time and work schedules, in order to avoid too much work-life conflict, as well as risks of stress, burnout and other illnesses, which can be not only detrimental for individuals, but also for organizations (Gillet, 2020). The paper addresses these main sources of risks related to human resources management from the point of view of time and schedule management mainly. The paper proceeds as follows. First, a literature review on time and time management issues and then the research methodology. Then, the results are presented and the paper deals with 1) the management of regulations concerning the definition of working time and its method of calculation. Next, it develops on 2) the intensification of work experienced by airline stewards, as this appears to be a major work change over recent years. Then, the paper analyzes 3 ) the fragmentation and heterogeneity of working times. Finally, the constraints of atypical working hours 4) are analyzed to show the management of schedules and the tensions that develop between professional, family and personal times and they include a diversity of working and non working times that are strongly intertwined.

\section{Time and time management issues}

The measurement of working time is an important issue in labor relations. Profoundly transformed over the past twenty years, working times are also the source of struggles, transactions or adjustments that reconfigure wage and employment relations (Clouet et al., 2019) in many industrial sectors.

The transformations of work organizations has increasingly questioned the forms and methods of measuring working time over the years (Sabel \& Zeitlin, 1997), and many industrial sectors present their own characteristics in relation to the dominant methods of calculation (Caracausi, 2011). Atypical or unpredictable working hours have indeed increased in most OECD countries (Presser, 2003; OCDE, 2004) and HR managers have to try to organize schedules in order to deal with the activity, without putting too much stress on employee's worklife balance. However, with many sectors working $24-7$, employees are increasingly confronted with atypical working hours, which affect well over one third of workers in Canada and the US (Tremblay, 2016) and 40\% of employment in France (Working conditions surveys, Dares, 2019). The airline sector is of particular interest from this point of view. 
For Cabin Crew, "working time" is a very peculiar concept, as there exists a variety of terms and definitions, such as "duty time" and "rotation" (work and "non-work" times related to flights). There are forms of work which include time associated with work but which would not necessarily be defined as working time in other occupations.

Research shows that the diversification of work schedules and time complicates the measurement of working hours and the clarity of the boundaries between actual working time and "free" time (Barrois, 2016; Barrois \& Devetter, 2017). On the one hand, the diversification of working times and rhythms, both daily, weekly and annual, has increased (Devetter, 2002; Lesnard, 2009; Bue \& Coutrot, 2009). On the other hand, the changes go beyond the length of working hours and concern the methods of determining working hours and the specific periods worked. One of the main issues is also that of the relation between periods of work and non-work (Michon, 2005; Lesnard, 2009). Even as working time has been generally reduced over the past decades and centuries, from a 6 day work-week to a 5 day and from 60 hours to 35 or 40 in many sectors (Tremblay, 2017), the overall domination of work in people's lives has increased (Pélisse, 2002).

The definition of the pace of work within working hours has changed and working time has intensified. The multiplication of potential urgent situations or technical or relational constraints further transforms and breaks the pace of work (Devetter \& de Conninck, 2012). The French Working Conditions survey, one of the few surveys documenting work pace and intensification, shows an increase in the pace of work imposed in airline transportation. In air transport, the hours of flight work are defined in various ways, mainly as concerns organization and length of schedules, but also pace of work.

Medium and long-haul flights require very diverse waking and sleeping patterns. The sleep/wake cycles of flight attendants are regularly altered and often disorganized and go against the rhythms of the physiological internal clock (Scheller, 2009).

There is very little research on Cabin Crew's working time and management issues; research is rare and somewhat dated (Gil, 1990; Cetcopra et al., 2000; Dubey \& Martin, 2001; Moricot, 2001). The few works on Cabin Crews have usually been done in a single airline, and there is little comparative work on working times in Airlines. There is also little work in sociology, although Hochschild (1983, 2003) constructed her concept of "emotional labor" on the basis of Cabin Crew's work. To our knowledge, no international research has been carried out so far to analyse the working times and rhythms of cabin crew and their experiences of it. Research is thus called for on time management in the airline sector and this research fills a gap for various airlines and countries (Gillet \& Tremblay, 2020a, 2020b).

While the primary mission of flight attendants is to provide a transport service to passengers, time is a major dimension of the job. To make the planes take 
off on time and get them to their destination, many activities are carried out and a variety of work schedules overlap. The work of the Cabin Crew is done in a very particular spatio-temporal framework, which is also subject to numerous rules and regulations. Several elements determine working time and influence the organization of work and working times of the Cabin Crew.

The cabin crew's activity is very strongly fragmented, broken up in a succession of distinct moments carried out with a specific rhythm, and in various places. Work takes place in multiple spaces, at each "flight cycle" or rotation, with a collective work which does not always last very long. Indeed, in addition to the specifics of the schedules, the teams of cabin crew and pilots are short-lived, getting together shortly before the flight and for only the duration of a given flight (or rotation, as they call it). This presents significant challenges for team cohesion, which is crucial for security.

In medium or long-term flights, the circadian rhythm is often not respected because of the shift schedules and night work. Also, changes in time zones due to geographic movements have jet lag effects. Finally, being frequently in flight in an aircraft exposes personnel to particular physical conditions (carrying heavy loads but also air conditioning, and certain harmful radiations from the sun). Working conditions and health are important issues in this sector, and these are elements to be considered, as well as the time constraints and challenges.

All of these issues of working times and rhythms mean there is a complex and often problematic articulation between times devoted to work activities and other social times (family and personal life). Let us recall the fact that there are about $65 \%$ of women in this occupational group of flight attendants (with small variations according to the companies and according to the position). Gender is therefore an important issue in the analysis of the effects of working time and time management on family or personal life. The research led us to analyze these times and "experiences", in relation with the multiple social times experienced by Cabin Crew.

This diversity of working times and schedules, leads to question management strategies and to question why and how these schedules are developed and if worklife balance could be better if some management practices were transferred from some countries and airlines to be adopted elsewhere.

While most airline companies are subject to similar working time or international regulation from the airline industry, there are some distinctions between countries or types of work. Certain national peculiarities will be highlighted, as they can offer interesting HRM solutions to the difficulties experienced elsewhere and illustrate ways that management could adjust or address working time issues specific to the work of the Cabin Crew.

\section{Methodology}

This article is based on our analyses of data collected from hostesses, stewards and flight directors in several airlines: regular, low cost or charter. 
We carried out 100 individual qualitative interviews-between $1 \mathrm{~h} 30$ and $3 \mathrm{~h} 30$ each, in France, Canada and Germany. The data were analyzed using the techniques of qualitative thematic content analysis by studying common themes or patterns emerging from the participants' discourse (Ghiglione et al., 1980; Mucchielli, 1996; Bardin, 2013; Drisko \& Maschi, 2016). The interviews were transcribed and analyzed, with some elements of documentary data used for comparative purposes. The themes were reworked with an in-depth and comparative analysis of transcriptions, field notes, and other studies (Patton, 1999).

We also distributed an online questionnaire (with 2000 respondents in the major airlines in Europe (France, Germany, Italy, Portugal, the Netherlands, Spain) and Canada. We do not indicate the names of the airlines as our university ethics norms require that they remain anonymous.

Our questionnaire is very detailed, which made it possible to collect objective and subjective data on our research questions. The questions deal with working time and its effects, work constraints, teamwork during flights, work of pilots and co-pilots in relation with the crew, the situation during stopovers, relations with passengers, work relationships, work-family and personal life integration, work-life measures, impact of work on stress, health and burnout, challenges in work, motivation and psychosocial climate. There were also questions on classic sociodemographic data such as sex, age, level of education, seniority and others related to family situation and work experience. We also made direct observations of the work of flight crews in flight. We also made direct observations of the work of flight crews in flight.

We had access to legal and internal documents from several airlines (collective agreements, internal reports, technical and commercial documents, etc.), as well as to historical archives. The analyses were based on a partnership research (Gillet \& Tremblay, 2017) with the unions representing the Cabin Crew Members of various airlines from several countries and the European Cabin Crew Association, representing $70 \%$ of all cabin crew in Europe.

This article is based mainly on the interviews done in Canada, France and Germany. The interviews covered working conditions (in particular working hours), work intensification, work organization, teamwork and working relations, the reconciliation of work and non-work times, health (stress, fatigue).

It is difficult to obtain a representative sample of all companies and countries. However, we sought to obtain a diversity of profiles and we selected, among the people who volunteered for an interview following their completion of the online questionnaire, people with diverse situations and experiences (sex, family situation, age and seniority in the job), and also people working in different contexts (short, medium and long haul; low cost and "national" companies). We carried out 100 interviews in the three countries (France $=41$, in three companies; Canada $=41$, in three companies; Germany $=18$, in one company).

For these interviews we met 67 women (France (27), Canada (33) Germany (7)); 33 men (France (14), Germany (11), Canada (8)). The ratio of women to 
men is the same as that found in the occupation, that is $2 / 3$ women and $1 / 3$ men). The diversity of occupations is also reprented as we met 58 hostesses/stewards and 42 chief pursers or cabin directors. The median seniority of participants was 17 years in Canada (from 3 to 38 years). In Germany it was of 9.5 years (from 1.5 to 27 years of seniority). In France it was 18 years (from 3 to 31 ). As for family responsibilities, 40 persons had children for whom they were responsible, 8 of them without a partner.

The majority of interviews in France and Canada were conducted face-to-face, some were conducted via videoconference, as were also those with Germany.

\section{The Definition of Working Time and Its Calculation}

Working time, its organization and its calculation are important issues in organizations (for employees, unions, employers), as many sociologists and ergonomists have shown-for other occupational categories. Several studies analyze the production of time standards and the multiplicity of new working times, the result of organizational work (de Terssac \& Lalande, 2002) carried out jointly by collective bargaining and by the legislator over a long period (Thoemmes, 2012).

Perhaps even more than for other professional groups, the activity of Cabin Crew is strongly regulated by formal work standards which govern the organization and performance of their tasks on multiple dimensions, including schedules, organization of working time (breaks, rest) and stopover time.

\subsection{Regulations and Conventions on Working Time: A Strategic Issue}

The work of the Cabin Crew is governed by many rules: national and international regulations, work standards, procedures. The rules are defined by various institutions: IATA (International Air Transport Association), ICAO (International Civil Aviation Organization), EASA (European Aviation Safety Agency), national transport ministries and by airlines (collective agreements). They are also regulated by codes (of civil aviation in the transport code), international conventions, European regulations in Europe and national transport departments in each country.

These various institutions intervene in the regulation of working time for cabin crew.

Working time is an issue of strong and strategic importance for HRM within airline companies, for workers, unions, and HR management. The unions are very active in several major airlines and the stewards and cabin crew members are very highly unionized.

Working time is thus governed by international rules in each country, with possible differences between airlines following negotiations and collective agreements between unions and employers. The actual working time can in fact be negotiated in each company and therefore can differ from the international, European or national standard if the conditions negotiated by unions are better 
than the general sectoral or national conditions (Miné, 2017, 2019). Various social regulations (Reynaud, 1991, 1997; de Terssac, 1992, 2016) thus produce time norms, which are strongly determined by various forms of regulations at the international and national level, but also by some medical and technical expertise.

Schedules are atypical and impose a very specific time frame: shifts, changing work schedules, often built using computer software (internal company system), where the schedule is determined from one month to the next. Schedules can sometimes change up to one week before the start of each month. It is therefore up to the staff to adapt to their flight schedule month by month, sometimes with difficulty, as they mentioned in the interviews:

"The difficulty is the schedules, it's special, with life ... We start at 4 am we go to bed at 10:30 pm, there is fatigue too, and it's very psychologically demanding because you always have to be in a good mood and calm if there is a problem (...) I do short and medium haul, that is to say between 1 and 5 flights with the same team; I do Eastern Europe, Spain, Italy, Morocco and Israel, from France... There is no stopover between 5 am and 12:30 pm... it is a flexible schedule that we know on the $17^{\text {th }}$ of the month before" $(\mathrm{Au}-$ rore, flight attendant).

"What is difficult about work are the sleepless nights, lack of sleep and physical fatigue. The pace is difficult, so is the age-related fatigue, I'm getting old..." (Virginie, flight attendant).

"The hardest part is changing schedules at the last minute... The company should improve the stability of the schedules" (Aurore, flight attendant).

In addition, a "reserve time" is required of each Cabin Crew Member. These are days in the year that are spent at the airport, on standby, in case a replacement has to be made at the last moment, just before a flight. Again, there are variations depending on the airline.

The organization of work and the management of working time (complex and computerized) have the effect of constituting, for the duration of a rotation, an "ephemeral" crew (Poirot-Delpech, 2016). The possibilities of having exactly the same team configuration on the next flights-on the following rotations are negligible. The working group is therefore temporary and, contrarily to what might be expected, most Cabin Crew Members consider this to be a positive aspect.

"The crew is ephemeral and that requires a great sense of adaptation, a lot of communication and having as little prejudice as possible... You have to be into your work right away and we all support each other. Not working with the same people all the time also makes it possible to evolve... there is no routine, always new personalities and people from other cities who teach me a lot of things" (Solène, flight attendant).

\subsection{Working Time and Service Time. The Management of "Working Time"}

Measuring working time is an important issue in labor relations, in particular as 
concerns excessive working hours and the variability of hours (Le Goff, 1960; Arnoux, 2009; Maitte \& Terrier, 2011, 2012; Thoemmes, 2009, 2012).

In the air transport sector and for flight personnel (technical: pilots; commercial: hostesses, stewards and flight managers or directors), the expression "working time" is not used in companies, where they refer to "Duty time" and "in-flight duty time".

In Europe, working time is measured by flight time and it must not exceed a maximum number of hours per year (740 hours) and per month (90 hours). In France, the duration of a flight period cannot exceed 10 hours within a range of 14 hours. The number of consecutive working days (including stopovers) is a maximum of 6 days and the number of flights per period of service (working) cannot exceed six. These hourly conditions depend on the type of company. They are more favorable for regular companies; or less favorable for low cost companies (number of hours, time off, etc.).

In Canada, the normal working hours are 8 hours per day and 40 hours per week, but they are 14 hours and may extend up to 16 hours per day for the Cabin Crew; in contrast, the normal number of hours worked per month is 75 hours. The company has management rights to extend this number to 85 hours, depending on operational requirements. In addition, flight attendants who wish to do so can work on a voluntary basis for up to 100 hours per month. Part-time options are also possible in some companies. The German company, for example, has over thirty part-time schedule models and the Cabin Crew Members interviewed seem to find these options interesting as they can find the arrangement that suits them best.

The number of monthly working hours seems low in the eyes of a worker doing standard hours, but the hours paid at the normal rate are limited from "door to door", that is to say from the moment when the blocks under the wheels of the airplane are removed before departure until the moment when they are put back after the complete shutdown of the plane, not including the time of stopover. There are many subtleties about this pay management system; however, in principle, the Cabin Crew Members are not paid on the ground, but only on the plane, in Canada as in Europe.

"So that we wait, we are not paid, it is not counted, so that in reality when we say that we must do sixty-five hours of flight, it is... I had already done the calculation in the past, but it's at least eighty hours, it's like fifteen hours that are not formally paid" (Cynthia, flight attendant).

The cabin crew's activity is fragmented into different times: the "Flight Time"; the "Flight Duty Time" (that is to say the flight time + a maximum of 1 h30 of ground activities related to the flight, before takeoff of the aircraft and after its landing); "Stopover" or time between two flights spent outside the flight attendant home base; "Reserve Time" (each flight attendant must provide a contingent of on-call hours, during which he may be called upon to make up for a last minute absence); and finally the "Rest Time". Peripheral flight times are there- 
fore numerous and not all of them are considered working time, even if there are tasks to be performed. There are also flight delays, additional time which is also not counted but which is integrated into the rotation and thus increases the effective working time. Each Cabin Crew Member performs an in-flight service: short, medium or long haul defined according to the distance and duration of the flight.

The interweaving of time with space to calculate and qualify types of flight is also something not found in other time management systems. Indeed, the shorthaul flights are of a distance of around $500 \mathrm{~km}$, the medium-haul flights do not exceed 3 hours to $3: 30$ and the distance is less than $5000 \mathrm{~km}$, and long-haul flights reach $15,000 \mathrm{~km}$. The type of flights (short, medium and long haul), in connection with the destinations and the durations, distinguish between schedules, working rhythms, and time differences.

The "actual lived time" is different according to these conditions determining the activity of the Cabin Crew Members. Also, family conditions (linked to gender and age) involve different work-life time management challenges, as our interviews have shown. The possibility to choose a given type of flight depends on the human resource management of the airline and the seniority of the cabin crew. Some will prioritize short hauls in order to get home at night to join their families, or because they have difficulties with jet lag.

"The more difficult it is to reconcile work and family and personal life, the more the fatigue associated with the schedules. The main motivation is the days off and the salary" (Célia, flight attendant).

Others will choose the medium or long hauls for the attractiveness and the diversity of destinations, or other amenities. When it is possible to choose a particular flight, depending on seniority and also the existence of software allowing these choices, individual preferences can vary according to a set of personal and family circumstances. Thus, some will prioritize a less popular destination in order to visit a loved one. Others will leave their weekends to mothers and fathers to take the week off and devote time to their studies, or just go shopping when they want. Our participants therefore had personal preferences and techniques to best organize their schedule according to their respective wishes.

"What I enjoy most about my job is traveling, discovering. The staggered hours, even if it is hard, I like it, I am not made to get up at a fixed time or to work with the same people..." (Virginie, flight attendant).

\section{Intensification of Work}

Work and its organization are increasingly characterized by processes of acceleration, densification and temporal desynchronization. The pressure of deadlines and speed of execution have taken hold of many sectors, including aviation. Behind these processes lie the logics of competitiveness, cost reduction, desire for increased market share and profits. Some studies have focused on emergencies at work, as in the large-scale retail sector with intensification of activity (Choquet, 
2012). Others have studied broken schedules in the maintenance sector of an airline (Monneuse, 2012), but no research was found on flight attendants, which we decided to study. In all these sectors, intensive work, in urgency, under stress, with work interruptions, appears to have become normal. Urgency is also valued in the managerial ideology which legitimizes time pressure, where speed and responsiveness are linked to success and performance (Boltanski \& Chiapello, 1999).

Moreover, new regulations are changing the hours and rhythms of work and intensifying the work of Cabin Crew. A 2016 European regulation (which the unions opposed) imposed new regulations and working time calculations for the Cabin Crew, resulting for some companies in less favorable working conditions than before: reduction in the number of staff per flight, reduction in stopover time and flight duration, taken into account in the calculations of the destination airport as the "base" airport-which increases the possibilities of longer working hours.

Computerization has also helped reduce stopover times over the years, by optimizing flight and stopover times in order to reduce costs, which translates into less rest time and an intensification of work. However, this was seen negatively as stopovers were considered one of the positive aspects of the profession; many Cabin Crew Members considered that the difficulties or the intensification of the work were compensated by the possibility of visiting new or very popular cities.

"We work more than before, we have more flights and the days are getting longer, in summer as in winter... and the time allocated to stopovers has decreased" (Francis, flight attendant).

In Canada, the Ministry of Transport authorized on August 1, 2015, the reduction of the minimum number of cabin crew on board aircraft, from a ratio of one flight attendant per 40 passengers to one per 50. This new measure, strongly contested by the Canadian Union of Public Employees, was intended to allow airlines to increase their productivity in a context of increased international competition and was applied from 2015 on (Desjardins, 2017).

"In the past the crew had time to sit down, take the time to eat and during this time I went around, I made sure that everyone was in a good mood, I asked if there were things that I had to bring back... but now when people sit down to eat I don't have time because if I don't eat I am penalized, after the five, ten minutes that I am allowed myself to eat, I have to go and take care of the passengers" (Jeanne, cabin director).

This time frame is experienced in a way that is all the more complicated as the work of Cabin Crew has undergone multiple changes leading to more technical, material and organizational constraints.

For the sake of productivity, the workload has increased, due to several factors:

- the reduction in the number of staff with a regularly reduced crew; 
- the diversification and intensification of work, with an increase in the standards and tasks to be performed during each flight (essentially commercial but also, and increasingly, safety and security, logistics and tasks related to cleanliness and hygiene on the aircraft);

- reduction in breaks, even compulsory, because it is sometimes impossible to take them on short flights (very reduced meal times);

- changes in passenger behavior (more difficult and risky passengers);

- changes in the activities of ground staff, which has the effect of increasing the work of flight attendants by shifting the division of labor. Indeed, following the transformations of ground activities (due to technological developments and machines), new tasks are to be performed by the cabin crew: responding to passenger requests for information on flights.

"We were eleven and we are eight, we lost three flight attendants on a plane. We have to redistribute the work, it's huge "(Bruno, cabin director).

"I give $90 \%$ of myself during the flights... If we do the job well, we never stop... We give people a lot and they are happy... It's a heavy workload and psychological and emotional" (Aude, flight attendant).

"With the mobile phone and the tablet we are autonomous and we also have more tasks to prepare for the flight, to set the objectives because we receive information on the passengers whereas before we only had a list of names... And we also receive other information to be managed at the same time as welcoming the passengers... digital action is more and more in demand" (Carole, cabin director)

"The number of Cabin Crew Members has decreased significantly over the past 10 years... Passengers have digital information and they ask us much more on board, on flights, timetables, connections... before they went to travel agencies" (Carole, cabin director).

Our results indicate a phenomenon of work intensification manifested by an increase in the number of passengers per flight attendant, a perceived reduction in on-board break times, an increase in the tasks to be performed and the physical efforts to be provided, as well as reduction in stopover times. So, over the past twenty years in particular, in the face of competition from Gulf countries and rising fuel prices, companies have used various strategies to intensify work, reduce downtime and reduce the length of time a plane is on the ground, which is not financially profitable.

"The workload is heavy, we are asked for more but always in a limited time, to save time. It's difficult... more responsibility in a shorter time; this it doesn't suit me and I don't want to rush “(Virginie, flight attendant).

In addition, the need for a supportive crew and cooperative collective work makes everyone's work easier. Airline personnel shares a strong work culture and a strong professional identity (Sainsaulieu, 1977; Dubar, 1991). They share a common professionalism, a set of behaviors, interests, values where teamwork, 
cooperation and solidarity are important.

"Teamwork is essential, otherwise we cannot work... In the cabin we will help a colleague who needs it, take over if there is a problem with a passenger" (Virginie, flight attendant).

"We try to make the working group important and to manage collectively... for example a problem with a passenger, you delegate the problem... We try to be united, and since the working conditions are harsher, it strengthens the links, we support each other" (Aurore, flight attendant).

The mechanical solidarity between the members of the group makes it possible to quickly overcome the functional division of tasks and share the management of emotions.

However, the generally protective role of this working group can be undermined due to the intensification of work because it is sometimes no longer possible to help a colleague (especially in some low cost airlines or depending on the type of flight).

\section{Fragmentation and Heterogeneity of Time in the Work of Flight Attendants}

We find in the Cabin Crew's work one of the major challenges of the last decades, which also affects other professional sectors: a form of "fragmentation" of working time (Quéinnec et al., 2000) in direct service professions where employees must be available according to needs: hotel and catering, cleaning or personal services for example. These jobs are marked by several periods of work, by working days "in broken hours", with many interruptions that can extend the time during which the employee is "subordinated to the job" (Barrois \& Devetter, 2017).

There are few professions where the "standard activity" is as fragmented in space, time and rhythm as is the case for the cabin crew. This is a major issue from the point of view of work-life balance, although some Cabin Crew appreciate these very diverse schedules.

Several activities are part of a chain of operations that prepare or continue work, outside the strict scope of the flight activity. Upstream and downstream of the flight, a multitude of tasks are performed to prepare the activities that will follow and control them.

The flight attendants have preparation activities before each flight (on their own time) using their tablet (i-pad) provided by the company. They consult and analyze information on the characteristics of flights, the characteristics of certain passengers that the crew must take into account: people requiring assistancechildren traveling alone, the elderly, sick or disabled, passengers with a frequent flyer status, passengers under police surveillance (repatriations, criminals).

"My role as cabin director is to coordinate everything, to oversee the cabin crew, to check the characteristics of the passengers, to inform the technical 
flight personnel because we are their eyes and ears... to ensure coordination with the staff on the ground, with the cleaning team by means of mobile phones..." (Patrick, cabin director).

At the time of the stopover, the pilots are already preparing the technicalities for the next flight. These various preparations are done either during formal moments when the work is visible; they are then counted in the actual working time. Or they are carried out during "invisible" time, i.e. carried out during personal time, before the rotation cycle, and are therefore not counted. Thus, this profession is based on a certain expansion of operations and working time, facilitated by digital tools, in a diversity of space and time. Training time in the form of e-learning for flight crews is frequent, carried out partly on their personal time, sometimes on their stopover time.

\section{The Constraints of Atypical Schedules}

Since the 1970s, employees have experienced transformations in working time, as recalled by numerous studies in economics and sociology (Bouffartigue, 2012; Thoemmes, 2000, 2012; Tremblay \& Soussi, 2020). In France and in other countries, with social struggles and negotiations, the legal working time has been strongly reduced over a century, and many work situations have improved. However, in certain sectors, work is still done under difficult conditions and with painful working times (Grossin, 1969, 1996). Numerous studies show that changes in working time question the organization of social times and work-family issues (Clark, 2000; de Terssac \& Tremblay, 2000; Lallement, 2003; Dubar, 2004; Thoemmes \& de Terssac, 2006; Barrère-Maurisson \& Tremblay, 2009; Dubar \& Thoemmes, 2013; Tremblay, 2013, 2019; Lambert, 2018).

Also, many professional sectors or trades do not fall within a working time standard identified by "office hours" from 9 a.m. to 5 a.m. or at a single, fixed location, as is the case for Cabin Crew, who have a diversity of working times and places. Likewise, in some industrial firms, shift work dominates (three eight hours shifts, with night shifts), as is the case in hospitals, with extended shifts and weekends. Sectors such as trade, tourism and catering, but also those of freight transport and public transport (road, rail, navigation) require specific schedules, adapted to the variability of services.

Following imposed and changing schedules is often the most important work constraint experienced by Cabin Crew, especially at the start of their careers or in companies that do not have a bidding system or a "flight exchange" system, that is "flight swaps" which may offer the possibility of swapping certain unwanted flights with a colleague who does not mind doing this flight.

\subsection{Work Schedules}

The cabin crew's work schedules are atypical and do not respect the circadian rhythm because of shift work, night work and the effects of jet lag. Working time rules have consequences on working conditions (links between working time 
and fatigue) but also on work-life balance (family-personal life/professional life), including some gender inequalities.

In Canada, the flight attendants interviewed indicated that the constraints are particularly difficult at the beginning. However, over the years, as they acquire seniority, they have priority in the choice of flights, which makes life easier for the majority of our participants. As a result, the constraints are not as strong or at least they have more choices.

On the other hand, in the different companies studied, some flight attendants do not wish to become a cabin director in order to maintain their seniority and priority in choosing schedules, which would be lost if they changed their work category. In particular for women with children, having less constraints or more weight in the choice of their schedules, because of increased seniority, is very important for work-family balance.

At the same time, the fact of having these atypical schedules can give some Cabin Crew Members a feeling of "freedom" and of recurring novelty, far from office hours ("9 to 5") and "routine at work". Indeed, a number of interviewees testified to the attraction of working outside " 9 to 5 ", as well as traveling and working outside a traditional office.

"I love my job too much, we are always in the center of action... the schedules are fine, as I'm so happy to travel... But we are all different as concerns managing fatigue and jet lag... You have to like this because it is very particular with the time constraints, the pace and the physical amplitudes" (Vincent, cabin director).

"It's a job where there is a lot of free time in this company, but it's physically exhausting" (Vincent, cabin director).

We were also surprised to see that some Cabin Crew Members, in particular women, say that this job allows them to spend more time, with their children, at certain times when they are not on a flight.

\subsection{Choice of Flight Preferences; Work Life Issues}

In the companies studied, the cabin crew can submit their flight time preferences and destinations on an online system, which evaluates them and allocates schedules according to seniority and availability.

Each month, flight attendants can submit their flight preferences for the following month. In their jargon, this is "bidding" (to bid): to apply for a given schedule. In fact, the airline has a computerized system based on the principle of supply and demand: the company posts its staffing needs online and the cabin crew will award points to the rotations that interest them more. However, you need to be familiar with the system in order to obtain the desired schedule, for example by avoiding requesting flights that require more seniority and which you won't get in any case.

The attractiveness of some flights depends on various factors, such as the destination (exoticism, cultural life, safety), time of departure (e.g. the need to leave 
at night), the length of the flight (maximization of hours worked), the need to commute for another flight once at destination ("set up"), stopover allowance, or the type of clientele (holidays and vacations, or regular travelers, sometimes less demanding), etc.

"I prefer to choose according to the duration of the flight and not according to the number of days worked in a row... I prefer to be paid less but to leave for a longer period and after that makes me less round trips from my base, for example destination Canton, over 6 - 7 consecutive days with 3 - 4 days of flight rotation and then $2-3$ days of rest afterwards" (Véronique, flight attendant).

However, even if everyone has a priori the same definition of what constitutes a difficult flight, some factors will be more important for some than for the others, so that not all are necessarily looking for the same flights.

In most companies, the cabin crew's schedule is therefore the result of a confrontation between the operational needs of the company and the personal needs of the flight attendants. As personnel advances in seniority, their needs may change. The ability to balance work and personal life improves over the years.

\section{Conclusion}

This research deals with a profession with strong specificities and challenges in terms of working time, social times and work spaces. The Cabin Crew's working time is specific due to the extent and complexity of the regulations and processes that determine it, by its very definition and its method of calculation. The organization of working time is subject to regulations, but also to significant collective constraints, flight hours and their contingencies being decisive in the organization of individual working time.

Even if schedules and mobility were accepted as an inherent characteristic of this profession, the organization of working and social time is very difficult at certain periods of life, and according to age, family situations and gender-for example, women most often take on family tasks and responsibilities. Work organisation then implies complex situations.

We have observed that some companies offer systems that make it possible for the Cabin Crew Members, with time and seniority, to better control their schedules; work-life balance then becomes easier.

The fragmentation of activities and working hours of a rotation is particular and has become more difficult over the years, with intensification of work. Through the analysis of the work of Cabin Crew we have seen fragmented work, both in its temporalities and in its intensity, in its contents and in its spaces.

Cabin crew's work is indeed highly fragmented; we are far from the conventional effective working time, reduced to a single space and time.

The working conditions, as well as the work-life challenges and the intensification of work, have consequences for the health of the flight crew and this is 
also an issue airline companies have to deal with.

Luckily for the companies, cabin crews are usually very passionate about their work. Thus even if the work implies strong constraints, significant investments (professional, emotional), a lot of organization and a particular way of life (schedules, absences, fatigue management and consideration of one's physical and mental health...) it is clear from all interviews that hostesses, stewards need to appreciate this occupation in order to stay in the long term.

Airline companies need to think about the future of this profession, as it is now hard hit by the COVID-19 pandemic, but also it was already somewhat transformed by more and more difficult working conditions and intensification of work, as well as elements that can affect health at work. In the future, will the profession become a simple "job", a job that could be carried out part-time, without a full career in the airline company, but for a period of a few years? Or will companies find new ways to engage workers fully in this occupation and give them the appreciation needed to stay on longer? With the intensification of work, all these elements also raise the question of the professional experience of flight attendants, with effects in terms of safety and flight safety.

With the pandemic, the coming months and years will see an evolution of the work and flight conditions. Although it is too early to know how the occupation will develop, it is highly likely that financial and health goals will continue to conflict, and choices will need to be made in the future.

The analysis of the schedules and working times of the Cabin Crew (flight attendants, stewards and cabin directors) reveals complex situations which can also pose questions pertinent other sectors, as our economies and societies evolve towards increasingly diversified working hours, and where work groups are formed and dismantled regularly. In this sense, the aviation sector and the Cabin Crew can be the precursors of tomorrow's work as well as the questions posed to management.

\section{Conflicts of Interest}

The authors declare no conflicts of interest regarding the publication of this paper.

\section{References}

Arnoux, M. (2009). Relation salariale et temps du travail dans l'industrie médiévale. Le Moyen Âge, 115, 557-581. https://doi.org/10.3917/rma.153.0557

Bardin, L. (2013). L'analyse de contenu. Paris: PUF. https://doi.org/10.3917/puf.bard.2013.01

Barrère-Maurisson, M.-A., \& Tremblay, D.-G. (2009). Concilier travail et famille. Le rôle des acteurs. France-Québec, Québec, PUQ. https://doi.org/10.2307/j.ctv18pgmsr

Barrois, A. (2016). La journée de travail: Organisation, valorisation et inégalités sociales. Thèse de doctorat en sciences économiques.

Barrois, A., \& Devetter, F.-X. (2017). Femmes salariées et non salariées: Quelles différences de temps de travail? Travail et emploi, 150, 101-130. 
https://doi.org/10.4000/travailemploi.7543

Boltanski, L., \& Chiapello, E. (1999). Le nouvel esprit du capitalism. Paris: Gallimard.

Bouffartigue, P. (2012). Temps de travail et temps de vie. Les nouveaux visages de la disponibilité temporelle. Paris: PUF.

Bue, J., \& Coutrot T. (2009). Horaires atypiques et contraintes dans le travail: Une typologie en six catégories. Premières synthèses Dares, mai, $\mathrm{n}^{\circ} 22.2$.

Caracausi, A. (2011). Mesurer et contrôler. Les temps de l'organisation du travail dans les manufactures de laine de Padoue (xvie-xviie siècles). Genèses, 85, 6-26. https://doi.org/10.3917/gen.085.0006

Cetcopra, Didrit, M., Gras, A., Martin, R., \& Moricot, C. (2000). Le métier de PNC. Rapport d'étude.

Choquet, J. (2012). Urgence et activité débordée dans le grand commerce. La nouvelle revue du travail [En ligne], 1.

Clark, S. C. (2000). Work/Family Border Theory: A New Theory of Work/Family Balance. Human Relations, 53, 747-770. https://doi.org/10.1177/0018726700536001

Clouet, H., Grimaud, P., Mias, A., \& Pélisse J. (2019). Tant de capital, temps de travail? Socio-économie du travail, 2, 6.

Dares (2019). Organisation du temps de travail. Synthèses stat No. 25.

de Terssac, G. (1992). Autonomie dans le travail. Paris: PUF.

de Terssac, G. (2016). L'activité dans le travail: Un point de vue sociologique. In M. A. Dujarier, C. Gaudart, A. Gillet, \& P. Lénel (Eds.). L'activité en théories. Regards croisés sur le travail (pp. 187-222). Toulouse: Octarès.

de Terssac, G., \& Lalande, K. (2002). Du train à vapeur au TGV: Sociologie du travail d'organisation. Paris: PUF.

de Terssac, G., \& Tremblay, D.-G. (2000). Où va le temps de travaiP? Toulouse: Octarès.

Desjardins, F. (2017). Ottawa refuse de resserrer les ratios d'agents de bord. Le Devoir [en ligne], en ligne le 24 octobre 2017.

Devetter, F.-X. (2002). Vers une nouvelle norme des temps de travail? Temps subis ou temps choisis (pp. 53-67). Formation Emploi.

Devetter, F.-X., \& de Coninck, F. (2012). Une transformation des temps de travail. Temporalités [En ligne], 16.

Drisko, J., \& Maschi, T. (2016). Content Analysis. New York: Oxford University Press. https://doi.org/10.1093/acprof:oso/9780190215491.001.0001

Dubar, C. (1991). La socialisation. Construction des identités sociales et professionnelles. Paris: A. Colin. https://doi.org/10.3406/forem.1991.1829

Dubar, C. (2004). Régimes de temporalités et mutation des temps sociaux. Temporalités [En ligne], 1.

Dubar, C., \& Thoemmes, J. (2013). Les temporalités dans les sciences sociales. Toulouse: Octarès.

Dubey, G., \& Martin, R. (2001). Les coulisses du ciel. Quaderni, 44, 89-100. https://doi.org/10.3406/quad.2001.1486

Ghiglione, R., Beauvois, J.-L., \& Chabronne, C. (1980). Manuel d'analyse de contenu. Paris: A. Colin.

Gil, A. (1990). Air Transport Deregulation and Its Implications for Flight Attendants. International Labour Review, 129, 317-330.

Gillet A. (Ed.) (2020). Formation et prévention des risques au travail. Education Perma- 
nente. $224 / 3$.

http://www.education-permanente.fr/public/articles/articles.php?id revue $=1767$

Gillet, A., \& Tremblay, D.-G. (2017). Les recherches partenariales et collaboratives, double édition: Rennes. PUR/Québec: PUQ. http://pur-editions.fr/detail.php?idOuv=4431

Gillet, A., \& Tremblay, D.-G. (2020a). Se former et apprendre en situation pour prévenir les risques aériens. Le cas du personnel navigant commercial (pp. 81-90.). Education Permanente, Formation et prévention des risques au travail 224/3.

http://www.education-permanente.fr/public/articles/articles.php?id revue=1767\&id ar $\underline{\text { ticle}=2920 \# \text { resume2920 }}$

Gillet, A., \& Tremblay, D.-G. (2020b). Les ressources du Personnel Navigant Commercial face aux évolutions des contraintes techniques, organisationnelles et temporelles de leur travail. In D.-G. Tremblay, \& S. A. Soussi (Eds.), Le travail à l'épreuve des nouvelles temporalités (pp. 25-52). Québec: PUQ. https://doi.org/10.2307/j.ctvvb7m9z.5

Grossin, W. (1969). Le Travail et le temps. Horaires, durées, rythmes. Paris: Anthropos.

Grossin, W. (1996). Pour une science des temps: Introduction à l'écologie temporelle. Toulouse: Octarès.

Hochschild, A. R. (1983). The Managed Heart: Commercialization of Human Feeling. Berkeley, CA: University of California Press.

Hochschild, A. R. (2003). Travail émotionnel, règles de sentiments et structure sociale. Travailler, 9, 19-49. https://doi.org/10.3917/trav.009.0019

Lallement, M. (2003). Temps, travail et modes de vie. Paris: PUF.

Lambert, A. (2018). Les incidences biographiques du travail mobile. Configurations familiales et rapport de genre. Année sociologique, 2, 68, 315-340.

https://doi.org/10.3917/anso.182.0315

Le Goff, J. (1960). Au Moyen Âge: Temps de l'Église et temps du marchand. Annales, 15-3, 417-433.

Lesnard, L. (2009). La famille désarticulée. Les nouvelles contraintes de l'emploi du temps. Paris: Presses Universitaires de France.

Maitte, C., \& Terrier, D. (2011). Une question (re)devenue centrale: Le temps de travail. Genèses, 85, 156-170. https://doi.org/10.3917/gen.085.0156

Maitte, C., \& Terrier, D. (2012). Conflits et résistances autour du temps de travail avant l'industrialisation. Temporalités [En ligne], 16.

Michon, F. (2005). Longues durées de travail, temps flexibles, temps contraints. Les nouveaux enjeux du temps de travail. Revue de I'IRES, 49, 9-33.

https://doi.org/10.3917/rdli.049.0009

Miné, M. (2017). Quand le droit favorise l’augmentation et la flexibilité du temps de travail. La nouvelle revue du travail [En ligne], 11.

Miné, M. (2019). Le droit du travail (30ème éd.). Paris: Eyrolles (Le grand livre).

Monneuse, D. (2012). La construction de l'urgence au travail et ses effets suivant les statuts hiérarchiques: Le cas des mécaniciens et des agents de maîtrise dans le secteur aérien. La nouvelle revue du travail [En ligne], 1

Moricot, C. (2001). The Changing Role of the Cabin Crew. Colloque Human Issues in Aviation System: Change, Cost and Reality. Ecole Nationale de l'Aviation Civile, Toulouse, septembre.

Mucchielli, A. (1996). Dictionnaire des méthodes qualitatives en sciences humaines et sociales. Paris: A. Colin.

OCDE (2004). Perspectives de l'emploi de l'OCDE. Paris: OCDE. 
Patton, M. Q. (1999). Enhancing the Quality and Credibility of Qualitative Analysis. Health Services Research, 34, 1189-1208.

Pélisse, J. (2002). A la recherche du temps gagné. Les 35 heures entre perceptions, régulations et intégrations professionnelles. Travail et Emploi, 90, 7-21.

Poirot-Delpech, S. (2016). Le collectif éphémère du personnel navigant sur les longs courriers. Socio-anthropologie, $\mathrm{n}^{\circ} 33$. https://doi.org/10.4000/socio-anthropologie. 2050

Presser, H. B. (2003). Race-Ethnic and Gender Differences in Nonstandard Work Shifts. Work and Occupations, 30, 412-439. https://doi.org/10.1177/0730888403256055

Quéinnec, Y., Barthe, B., \& Verdier, F. (2000). Réduction du temps de travail et organisation de l'activité au travail: des rapports ambigus et complexes. In G. de Terssac, \& D. Tremblay (Eds.), Où va le temps de travail? (pp. 133-142). Toulouse: Octarès Éditions.

Reynaud, J.-D. (1991). Pour une sociologie de la régulation sociale. Sociologie et sociétés, 23, 13-26. https://doi.org/10.7202/001632ar

Reynaud, J.-D. (1997). Les règles du jeu: L'action collective et la régulation sociale. Paris: A. Colin.

Sabel, C., \& Zeitlin J. (1997). World of Possibilities. Flexibility and Mass Production in Western Industrialization. Cambridge: Cambridge University Press. https://doi.org/10.1017/CBO9780511563652

Sainsaulieu, R. (1977). L'identité au travail. Les effets culturels de l'organisation. Paris: PFNSP.

Scheller, L. (2009). Le temps des conductrices de bus. Temporalités [En ligne], 9.

Thoemmes, J. (2000). Vers la fin du temps de travai? Paris: PUF.

Thoemmes, J. (2009). Les temporalités sociales: Mise en marché et conflits. Temporalités [En ligne], 10.

Thoemmes, J. (2012). La fabrique des normes temporelles du travail. Nouvelle Revue du travail, Temps professionnels éclatés, TIC et urgences, 1.

Thoemmes, J., \& de Terssac, G. (2006). Les temporalités sociales: Repères méthodologiques. Toulouse: Octarès.

Tremblay, D.-G. (2013). Temporalités sociales, temps prescrits, temps institutionnalisés. Québec: PUQ.

Tremblay, D.-G. (2016). Economie du travail. Les réalités et les approches théoriques (Édition revue, 482 p.). Québec: Presses de l'université du Québec. https://www.puq.ca/catalogue/livres/economie-travail-edition-3139.html

Tremblay, D.-G. (2017). L'éclatement de l'emploi (3rd ed., 104 p). Québec: Presses de l'université du Québec. http://puq.ca/catalogue/livres/eclatement-emploi-1734.html

Tremblay, D.-G. (2019). Conciliation emploi-famille et temps sociaux (4e éd.). Québec: PUQ. https://doi.org/10.2307/j.ctv10qqxm1

Tremblay, D.-G., \& Soussi, S. A. (2020). Le travail à l'épreuve des nouvelles temporalités. Québec: PUQ. https://doi.org/10.2307/j.ctvvb7m9z 